\title{
Pola Makan dan Hubungannya Terhadap Kadar Asam Urat
}

\author{
Elvie Febriani Dungga \\ Fakultas Kedokteran Universitas Negeri Gorontalo \\ Email: elviefebrianidungga@yahoo.com
}

\begin{abstract}
Abstrak
Penyakit asam urat biasa dikenal dengan Gout Arthritis merupakan penyakit yang ditandai dengan serangan mendadak, berulang dan nyeri. Asam urat merupakan hasil akhir metabolisme dari purin. Secara garis besar bahwa purin didapatkan dari makanan, jika pola makan tidak dirubah kadar asam urat dalam darah yang berlebihan akan menimbulkan menumpuknya kristal asam urat, apabila kristal tebentuk dalam cairan sendi maka akan terjadi serangan nyeri yang hebat dan timbul secara mendadak. Penelitian ini bertujuan untuk mengetahui hubungan pola makan terhadap kadar asam urat di Wilayah Kerja Puskesmas Telaga Kabupaten Gorontalo. Desain penelitian ini menggunakan pendekatan kuantitatif dengan rancangan Cross Sectional, Tehnik sampling yang digunakan adalah Purposive sampling dengan jumlah sampel 60 responden. Pengumpulan data menggunakan kuisioner dan lembar observasi. Diuji dengan menggunakan analisis Chi-square. Hasil penelitian menunjukkan terdapat hubungan antara pola makan dengan kadar asam urat $(p$-Value $=0,023)$. Kesimpulan terdapat hubungan antara pola makan terhadap kadar asam urat di Wilayah Kerja Puskesmas Telaga Kabupaten Gorontalo. Disarankan kepada masyarakat lingkungan kerja Puskesmas Telaga Kabupaten Gorontalo agar menjaga pola makan yang baik serta mau memeriksakan diri ke pusat pelayanan kesehatan terdekat secara rutin.
\end{abstract}

Kata Kunci

: Pola Makan, Kadar Asam Urat.

\begin{abstract}
Gout is also known as Gout Arthritis, is a disease characterized by sudden, recurrent and painfull attacks. Uric acid is the end product of purine metabolism. Broadly speaking, purines are obtained from food. Thus, if the diet is not changed, the excessive uric acid level in the blood will cause the accumulation of uric acid crystals which cause severe and suddenly arise pain when the crystals are formed in the joint fluid. This reseach aimed to determine the relationship between diet in the uric acid level in the Work Area of Telaga Publich Health Center, Gorontalo District. This research design used a quantitative approach with a cross-sectional design. The sampling technique used was purposive sampling with a sample of 60 respondents. The sampling were collected using questionnaires and observation sheets and tested using Chi-square analysis. The result showed that there was a relationship between diet and uric acid level ( $p$-value $=0,023$ ). The conclusion is that there is a relationship between diet on the uruc acid level in the Work Area of the Telaga Health Center, Gorontalo District. Recomended that the people in the Work Area of the Telaga Health Center, Gorontalo District to maintains a good diet and always to check their uric acid level at the public health center.
\end{abstract}

Keywords : Diet, Uric Acid Level

\section{PENDAHULUAN}

Penyakit asam urat atau yang biasa dikenal dengan gout arthritis merupakan suatu penyakit yang diakibatkan karena penimbunan Kristal monosodium urat didalam tubuh seseorang. Penimbunan Kristal monosodium tersebut jika berlebih didalam tubuh dapat mengakibatkan timbulnya asam urat atau gout arthritis itu sendiri. Asam nukleat terdapat didalam inti sel tubuh merupakan salah satu komponen yang terdapat dalam kandungan purin dan hal ini akan menyebabkan terjadinya asam urat (Jaliana, Suhadi, \& Sety. 2018).

Pada orang dewasa di Amerika Serikat didapatkan penyakit gout itu sendiri mengalami peningkatan dan 
mempengaruhi 8.3 juta (4\%) orang amerika. Pada tahun 2016 di China prevalensi hiperurisemia sebanyak 25,3\% dan pada gout adalah sebanyak 0,36\%, terjadi pada dewasa usia 20-74 tahun (Syahradesi. 2020).Sedangkan prevalensi hiperurisemia juga mengalami peningkatan dan mempengaruhi $43.300 .000 \quad(21 \%)$ orang dewasa di Amerika Serikat itu sendiri. Penelitian di Taiwan pada tahun 2013 terdapat prevalensi penyakit gout arthritis sebesar $41,4 \%$ dan juga meningkat sebesar $0,5 \%$ setiap tahunnya (Songgigilan \& Kundre. 2019).

Berdasarkan data WHO (World Health Organization) dalam Non-Communicable Dissease Country Profile (2011) di Indonesia prevalensi penyakit asam urat pada usia 55-64 tahun berkisar pada 45\%, dan pada usia 65-74 tahun berkisar pada $51,9 \%$, serta usia $>75$ tahun berkisar pada $54,8 \%$ (Syarifuddin, Taiyeb, \& Caronge. 2019). Prevalensi gout arthritis di Indonesia pada tahun 2018 berkisar sebesar 11,9\%, dengan Aceh sebanyak 18,3\%, serta Jawa Barat sebanyak 17,5\%, dan Papua sebanyak 15,4\%. Berdasarkan gejala gout arthritis di Nusa Tenggara timur sebanyak $33,1 \%$, begitu pula Jawa Barat sebanyak $32,1 \%$, dan Bali juga sebanyak 30\% (Syahradesi. 2020).
Berdasarkan data RISKESDAS 2018 prevalensi penyakit sendi di Gorontalo berada pada urutan ke-16 dari 34 provinsi dan berdasarkan diagnosis usia 45-54 tahun mencapai 11,1\%, usia 55-64 tahun mencapai $15,5 \%$, dan usia 65-74 tahun mencapai $18,6 \%$ dengan jumlah keseluruhan total terbanyak yakni didominasi oleh wanita $8,5 \%$ dibanding pria $6,1 \%$. Hal tersebut dapat dilihat dari banyaknya penderita asam urat yang ada dan terbanyak adalah dari usia 45 tahun sampai 74 tahun dengan kategori pra lansia dan lansia memiliki tingkat kadar asam urat yang berlebih.

Pada tahun 2017 Dinas Kesehatan Provinsi Gorontalo didapatkan bahwa data terbanyak yang masuk dalam 10 kategori penyakit terbanyak yaitu radang sendi dengan urutan ketiga setelah hipertensi, didapatkan total keseluruhan ada 14.391 penduduk Provinsi Gorontalo yang menderita gout arthritis (Badan Pusat Statistik Provinsi Gorontalo. 2017).

Secara garis besar bahwa purin didapatkan dari makanan, dengan pola makan yang mengandung purin secara berlebihan adalah faktor yang menyebabkan masyarakat akan mengalami asam urat. Hal ini masih kurang disadari masyarakat tentang konsumsi purin yang berlebih dapat meningkatkan kadar asam 
urat dalam darah dengan kurang memperhatikan pola makan yang mengandung purin meliputi frekuensi makan, jenis makanan, dan jumlah makanan (Ridhoputrie, Karita, Romdhoni, \& Kusumawati. 2019)

Berdasarkan hasil observasi awal pada tempat penelitian itu sendiri yakni di Wilayah Kerja Puskesmas Telaga Kabupaten Gorontalo didapatkan 5 responden (4 perempuan 1 laki-laki) dengan usia 45-65 tahun dan hasil wawancara menggunakan kuesioner pengukuran pola makan meliputi frekuensi dan jumlah makanan didapatkan masingmasing responden memiliki frekuensi makanan yang banyak dengan sering mengkonsumsi bahan utama yang mengandung purin tinggi dan sudah menjadi kebiasaan responden itu sendiri sebagai pengganti lauk, yaitu tahu tempe serta kangkung yang mengandung purin merupakan makanan favorit responden dengan frekuensi dan jumlah makanan yang banyak.

\section{METODE PENELITIAN}

Penelitian ini dilakukan di Puskesmas Telaga Kabupaten Gorontalo dari tanggal 26 April-4 Mei 2021. Rancangan penelitian yang digunakan adalah deskripsi korelasi menggunakan pendekatan Cross sectional. Tehnik pengambilan sampel yang digunakan adalah Purposive sampling. Sampel dalam penelitian ini yakni masyarakat yang berada di Wilayah kerja Puskesmas Telaga Kabupaten Gorontalo yang berjumlah 60 orang. Tehnik pengumpulan data menggunakan kuisioner dan metode pengukuran kadar asam urat.

\section{HASIL PENELITIAN}

Tabel 1. Hasil Analisa Univariat responden berdasarkan pola makan

\begin{tabular}{|c|c|c|c|}
\hline No & Pola Makan & N & \% \\
\hline 1 & Baik & 37 & 61,7 \\
2 & Tidak Baik & 23 & 38,3 \\
\hline \multicolumn{2}{|c|}{ Total } & $\mathbf{6 0}$ & $\mathbf{1 0 0}$ \\
\hline
\end{tabular}

Sebagian besar responden memiliki pola makan yang baik dengan jumlah sebanyak 37 responden $(61,7 \%)$ dan responden yang memiliki pola makan tidak baik dengan jumlah sebanyak 23 responden $(38,3 \%)$

Tabel 2. Hasil Univariat responden berdasarkan Kadar asam urat

\begin{tabular}{|c|c|c|c|}
\hline No & Kadar Asam Urat & N & \% \\
\hline 1 & Normal & 24 & 40 \\
2 & Diatas Normal & 36 & 60 \\
\hline \multicolumn{2}{|c|}{ Total } & $\mathbf{6 0}$ & $\mathbf{1 0 0}$ \\
\hline
\end{tabular}

Sebagian besar responden memiliki kadar asam urat yang diatas normal dengan jumlah sebanyak 36 responden $(60 \%)$ dan yang memiliki kadar asam urat normal yaitu dengan jumlah sebanyak 24 responden $(40 \%)$. 
Tabel 3. Hasil Uji Statistik Hubungan Pola Makan terhadap Kadar Asam Urat di Wilayah Kerja Puskesmas Telaga Kabupaten Gorontalo

\begin{tabular}{|c|c|c|c|c|c|c|c|}
\hline \multirow{3}{*}{$\begin{array}{c}\text { Pola } \\
\text { Makan }\end{array}$} & \multicolumn{4}{|c|}{ Kadar Asam Urat } & \multirow{2}{*}{\multicolumn{2}{|c|}{ Total }} & \multirow{2}{*}{$\begin{array}{l}\text { p- } \\
\text { Va } \\
\text { lue }\end{array}$} \\
\hline & \multicolumn{2}{|c|}{ Normal } & \multicolumn{2}{|c|}{$\begin{array}{l}\text { Diatas } \\
\text { Normal }\end{array}$} & & & \\
\hline & $\mathrm{N}$ & $\%$ & $\mathrm{~N}$ & $\%$ & $\mathrm{~N}$ & $\%$ & \\
\hline Baik & 19 & 31,7 & 18 & 30,0 & 37 & 61,7 & 0 \\
\hline $\begin{array}{c}\text { Tidak } \\
\text { Baik }\end{array}$ & 5 & 8,3 & 18 & 30,0 & 23 & 38,3 & 23 \\
\hline Total & 24 & 40 & 36 & 60 & 60 & 100 & \\
\hline
\end{tabular}

Nilai uji Chi-Square didapatkan nilai $p$-Value $=0,023(<0,05)$ artinya terdapat hubungan yang bermakna dan siginifikan antara Pola Makan terhadap Kadar Asam urat di Wilayah Kerja Puskesmas Telaga Kabupaten Gorontalo.

\section{PEMBAHASAN}

\section{Pola Makan}

Berdasarkan hasil penelitian yang dilakukan pada 60 responden yang berada di Wilayah Kerja Puskesmas Telaga Kabupaten Gorontalo untuk hasil pola makan itu sendiri terbagi atas dua kategori yaitu pola makan baik dan pola makan tidak baik. Hasil yang didapatkan oleh peneliti dari penelitian ini yaitu responden lebih dominan memiliki pola makan yang baik yaitu terdapat 37 responden dan yang memiliki pola makan tidak baik yaitu terdapat 23 responden, dan yang memiliki kadar asam urat diatas normal didominasi oleh responden yang memiliki pola makan tidak baik dan baik dengan jumlah 18 responden.
Menurut Flaurensia dkk (2019) menyatakan bahwa kebiasaan mengkonsumsi makanan-makanan yang mengandung tinggi purin yang sering dapat meningkatkan kadar asam urat dalam darah. Menurutnya purin yang terkandung dalam makanan akan diubah menjadi asam urat, purin itu sendiri merupakan salah satu senyawa basa organik yang menyusun asam nukleat atau inti dari sel-sel yang termasuk dalam kelompok asam amino, unsur pembentuk protein. Asam urat yang terdapat dalam tubuh kita tidak boleh berlebihan, asam urat yang berlebih ini disebabkan adanya pemicu yaitu makanan dengan senyawa lain yang banyak mengandung purin.

Hasil penelitian ini sejalan dengan penelitian (Rini, 2017) yang menunjukkan adanya hubungan pola makan konsumsi purin dengan kadar asam urat pada lansia di Posyandu Peduli Insani Mendungan Desa Pabelan Kecamatan Kartasura Kabupaten Sukoharjo dengan nilai signifikansi atau $p$ Value $=0,001$, maka dari itu dapat disimpulkan bahwa salah satu faktor utama dari beberapa faktor yang ada bahwa makanan kaya akan purin dan makanan laut mempunyai pengaruh yang cukup besar hal ini karena purin yang terdapat didalam bahan makanan terdapat didalam asam nukleat yang berupa nukleoprotein, ketika 
makanan yang mengandung purin ini dikonsumsi maka terjadi penguaraian dalam usus asam nukleat ini akan dibebaskan dari nukleoprotein oleh enzim pencernaan, dan selanjutnya asam nukleat ini akan dipecah menjadi purin dan pirimidin kemudian tahap akhir dari penguraian purin ini dilakukan oleh enzim xantin oksidase dan selanjutnya xantin oksidase ini akan membentuk asam urat.

\section{Kadar Asam Urat}

Berdasarkan hasil penelitian yang dilakukan pada 60 responden yang berada di Wilayah Kerja Puskesmas Telaga Kabupaten Gorontalo untuk hasil kadar asam urat itu sendiri terbagi atas dua kategori yaitu kadar asam urat normal dan kadar asam urat diatas normal. Hasil yang didapatkan oleh peneliti dari penelitian ini yaitu responden lebih dominan memiliki kadar asam urat diatas normal yaitu terdapat 36 responden dan yang memiliki kadar asam urat normal yaitu terdapat 24 responden.

Menurut (Ridhoputrie dkk, 2019) asam urat itu sendiri merupakan hasil akhir metabolisme dari purin, sebagian besar dari purin ini berasal makanan terutama daging, jeroan, beberapa jenis sayuran dan kacangkacangan. Kadar asam urat dalam tubuh dapat dipengaruhi oleh beberapa faktor contohnya seperti pola makan dan gaya hidup, untuk peningkatan kadar asam urat yang berlebihan dapat disebabkan oleh dua kemungkinan utama yaitu kelebihan produksi asam urat dalam tubuh atau terhambatnya pembuangan asam urat oleh tubuh itu sendiri. Dalam keadaan yang normal, asam urat ini dapat larut dalam darah pada tingkat tertentu, dan apabila kadar asam urat dalam darah melebihi daya larutnya, maka plasma darah akan menjadi sangat jenuh dan keadaan inilah disebut dengan hiperurisemia atau penyakit asam urat.

Hasil penelitian ini sejalan dengan penelitian (Jaliana dkk 2018) yaitu faktorfaktor yang berhubungan dengan kejadian asam urat pada usia 20-44 tahun di RSUD Bahteramas Provinsi Sulawesi Tenggara tahun 2017, dalam penelitiannya yang bertujuan untuk mengetahui hubungan dari faktor-faktor pencetus asam urat seperti mengetahui hubungan antara kadar asam urat dengan purin, hubungan kadar asam urat dengan aktivitas fisik, hubungan kadar asam urat dengan stress, bahkan hubungan kadar asam urat dengan riwayat keluarga.

c. Hubungan Pola Makan terhadap Kadar Asam Urat

Hasil menunjukkan bahwa sebagian besar masyarakat yang berada di Wilayah Lingkungan Kerja Puskesmas Telaga 
Kabupaten Gorontalo memiliki pola makan tidak baik dan hal ini dibuktikan dengan banyaknya data yang diperoleh yaitu banyaknya responden yang memiliki pola makan yang baik. Hasil uji ChiSquaredidapatkan nilai $p$-Value $=0,023$ $(<0,05)$, maka dari itu H0 ditolak yang artinya terdapat hubungan yang bermakna dan signifikan antara pola makan dengan kadar asam urat di Wilayah Kerja Puskesmas Telaga Kabupaten Gorontalo.

Responden yang memiliki pola makan baik dengan kadar asam urat diatas normal ada 18 responden, hal ini artinya dari 18 responden yang memiliki kadar asam urat diatas normal namun memiliki pola makan yang baik dikarenakan salah satu faktor seperti faktor aktivitas fisik yang mereka miliki ataupun faktor-faktor penunjang lain seperti usia, jenis kelamin, berat badan maupun tinggi badan serta masih banyak lagi yang dapat meningkatkan terjadinya peningkatan kadar asam urat diatas normal.

Responden yang memiliki pola makan tidak baik dengan kadar asam urat diatas normal ada 18 responden, hal ini artinya dari 18 responden yang memiliki kadar asam urat diatas normal dan memiliki pola makan tidak baik dan sesuai dengan hasil penelitian bahwa hal ini dikarenakan adanya pola makan yang tidak baik dari responden serta responden juga memiliki aktivitas fisik yang tinggi, ataupun kedua faktor ini dapat sangat mempengaruhi untuk peningkatan kadar asam urat seseorang.

Hasil penelitian ini juga sejalan dengan penelitian (Jaliana dkk 2018) yang menunjukkan adanya hubungan pola makan konsumsi purin dengan kadar asam urat pada usia 20-44 tahun di RSUD Bahteramas Provinsi Sulawesi Tenggara Tahun 2017 dengan nilai signifikansi atau $p$-Value $=0,043$, maka dari itu dapat disimpulkan bahwa makanan yang mengandung zat purin yang tinggi akan diubah menjadi asam urat, hal ini karena tubuh menyediakan $85 \%$ senyawa purin untuk kebutuhan setiap harinya dan purin didapatkan dalam makanan terutama udang, seafood, cumi, kepiting, kerang, dan masih banyak lagi makanan yang mengandung purin tinggi lainnya dapat berakibat langsung dari pembentukan asam urat yang berlebih atau bahkan akibat penurunan ekskresi asam urat yang terlalu banyak dengan kandungan purin yang ada pada makanan dapat meningkatkan produksi asam urat itu sendiri.

Hasil penelitian ini juga sejalan dengan penelitian (Hambatara dkk 2018) yang menunjukkan adanya hubungan konsumsi asupan makanan yang 
mengandung purin dengan kadar asam urat pada lansia di Desa Tulungrejo Kecamatan Ngantang dengan nilai signifikansi atau $p$ Value $=0,014$, maka dari itu dapat disimpulkan bahwa terdapat hubungan yang signifikan antara pola makan dengan kadar asam urat hal ini karena seseorang yang mengalami atau memiliki kadar asam urat diatas normal dapat disebabkan oleh beberapa faktor dan salah satunya adalah makanan yang dikonsumsi mengandung purin terlalu tinggi, dan purin ini merupakan satu senyawa yang dimetabolisme didalam tubuh dan menghasilkan produk akhir yaitu asam urat.

Menurut (Jaliana dkk 2018) dalam penelitiannya menjelaskan bahwa terdapatnya hubungan antara pola makan konsumsi makanan yang mengandung purin dengan kadar asam urat hal ini karena terdapat hubungan yang positif atau memiliki makna antara pola makan dengan penyakit asam urat dengan maksud atau pengertiannya bahwa semakin sering mengkonsumsi pola makan dengan kadar purin maka semakin tinggi nilai kadar asam urat, karena gangguan metabolik ini (asam urat) merupakan peningkatan kadar asam urat dalam darah yang disebabkan oleh peningkatan produksi (overproduction), penurunan pengeluaran (underexcretion) asam urat melalui ginjal, purin juga selain didapat dari makanan juga dapat berasal dari penghancuran sel-sel yang sudah tua. Pembuatan atau sintesa purin ini juga dilakukan oleh tubuh sendiri dari bahanbahan seperti $\mathrm{C} 0$, glutamin, asam aspartat, folat dan glisin. Hal ini diduga metabolit purin diangkut kehati, lalu melalui oksidasi yang akan diubah menjadi asam urat, dan kelebihan asam urat akan dibuang melalui ginjal.

Beberapa pendapat menyatakan bahwa purin yang terdapat dalam makanan didalamya terdapat asam nukleat berupa nukleoprotein yang ketika dikonsumsi didalam usus maka asam nukleat ini akan dibebaskan dari nukleoprotein oleh enzim pencernaan dan selanjutnya asam nukleat ini akan dipecah lebih lanjut menjadi purin dan pirimidin lalu purin akan teroksidasi menjadi asam urat. Maka dari itu jika pola makan tidak dirubah kadar asam urat dalam darah yang berlebihan akan menimbulkan menumpuknya kristal asam urat, dan apabila kristal tebentuk dalam cairan sendi maka akan terjadi yang namanya penyakit gout(asam urat) dan hal yang ditakutkan jika lebih parah lagi terjadi penimbunan diginjal maka tidak menutup kemungkinan akan menumpuk menjadi batu asam urat(batu ginjal) (Prasteyanigrum \& Amalia, 2016). 
Dalam penelitian ini peneliti berasumsi bahwa mayoritas masyarakat yang berada di Wilayah Kerja Puskesmas Telaga Kabupaten Gorontalo sebagian besar yang memiliki pola makan tidak baik yang mempunyai kadar asam urat diatas normal hal ini berarti memiliki hubungan antara pola makan dengan kadar asam urat, sehingga hal ini menunjukkan masyarakat yang memiliki asupan konsumsi purin berisiko dengan kadar asam urat dan masyarakat menyatakan bahwa mereka memiliki kebiasaan tidak merubah pola makan setelah mengetahui bahwa dirinya didiagnosa menderita asam urat dan masyarakat masih tetap mengkonsumsi makanan sumber purin yang harusnya dilarang setelah didiagnosa memiliki kadar asam urat diatas normal. Hal ini biasanya disebabkan karena adanya faktor sosial ekonomi yang merupakan faktor paling menentukan kualitas dan kuantitas makanan yang mereka konsumsi atau peroleh, selain hal tersebut masyarakat mengatakan bahwa makanan tersebut mudah dijangkau dan sudah tersedia juga lebih hemat dan lebih mudah dalam penyediaan makanan yang mengandung purin ini. Tanpa masyarakat sadari bahwa terutama bagi mereka masyarakat penderita kadar asam urat tinggi sangat berpeluang meningkatnya metabolisme purin didalam tubuh yang menghasilkan kadar asam urat berlebih didalam darah.

Peneliti juga berasumsi bahwa jika responden yang memiliki pola makan tidak baik namun memiliki kadar asam urat yang normal hal ini bisa saja dikarenakan adanya faktor-faktor lain contohnya seperti mengkonsumsi terlalu berlebihan dengan berbagai kandungan yang ada dalam makanan yang dapat membuat pola makan responden itu sendiri menjadi buruk ataupun tidak baik, begitupun sebaliknya apabila responden memiliki pola makan yang baik namun memiliki kadar asam urat diatas normal hal ini juga dapat dikarenakan beberapa faktor yang dapat meningkatkan kadar asam urat responden

\section{Simpulan}

Berdasarkan hasil penelitian dan pembahasan yang telah diuraikan sebelumnya, maka dapat disimpulkan bahwa terdapat hubungan yang signifikan antara pola makan terhadap kadar asam urat di Wilayah Kerja Puskesmas Kabupaten Gorontalo.Sehinggadiharapkan agar menjaga pola makan yang baik serta mau memeriksakan diri ke pusat pelayanan kesehatan terdekat secara rutin. 


\section{DAFTAR PUSTAKA}

Badan Pusat Statistik. 2017. Jumlah Penyakit Menonjol. Gorontalo: BPS

Fitriana, G. G., \& Fayasari, A. (2020). Pola Konsumsi Sumber Purin, Aktivitas Fisik Dan Status Gizi Dengan Kadar Asam Urat Pada Lansia Di Puskesmas Kecamatan Makasar Jakarta. Jurnal Gizi Dan Pangan Soedirman, 4(1), https://doi.org/10.20884/1.jgps.202 0.4 .1 .2590

Flaurensia, V., Kussoy, M., \& Wowiling, F. (2019). Asam Urat Di Puskesmas, 7(November), 1-7. Hambatara, S. A., Sutriningsih, A., \& Warsono. (2018). Hubungan Antara Konsumsi Asupan Makanan Yang Mengandung Purin Dengan Kadar Asam Urat Pada Lansia Di Desa TulungrejoKecamatan Ngantang. Nursing News, 3(1), 719-728

Jaliana, Suhadi, \& Sety, L. O. M. (2018). faktor-faktor yang berhubungan dengan kejadian asam urat pada usia 20-44 tahun di RSUD

Batheramas provinsi sulawesi tenggara tahun 2017. Jimkesmas, $3(2), 1-13$. Retrieved fromhttp://ojs.uho.ac.id/index.php/J IMKESMAS/article/download/392 $5 / 3003$

Prasetyaningrum, E., \& Amalia, Y. (2016). Pengaruh pola hidup terhadap kenaikan asam urat. Sekolah Tinggi Ilmu Farmasi, 1-6.

Ridhoputrie, M., Karita, D., Romdhoni, M. F., \& Kusumawati, A. (2019). Hubungan Pola Makan Dan Gaya Hidup Dengan Kadar Asam Urat Pralansia Dan Lansia Di Wilayah Kerja Puskesmas I Kembaran, Banyumas, Jawa Tengah. HerbMedicine Journal, 2(1), 43-50. https://doi.org/10.30595/hmj.v2i1.3 481
Rini . (2017). Hubungan Jenis Kelamin dan Asupan Purin dengan Kadar Asam Urat pada Lansia di Posyandu Peduli Insani Mendungan Desa Pabelan Kecamatan Kartasura Kabupaten Sukoharjo. (Publikasi Ilmiah, Universitas Muhammadiyah Surakarta). Diakses pada $28 \mathrm{Mei}$ 2021 darihttp://eprints.ums.ac.id/49781/2 4/NASKAH\%20PUBLIKASI.pdf

Riset Kesehatan Dasar. 2018. Jumlah Penderita Penyakit Sendi. Kemenkes RI: RISKESDAS

Songgigilan, A. M. G., \& Kundre, R. (2019). Hubungan Pola Makan Dan Tingkat Pengetahuan Dengan Kadar Asam Urat Dalam Darah Pada Penderita Gout Artritis Di Puskesmas Ranotana Weru. Hubungan Pola Makan Dan Tingkat Pengetahuan Dengan Kadar Asam Urat Dalam Darah Pada Penderita Gout Artritis Di Puskesmas Ranotana Weru, 7(1), $1-8$.

Syahradesi, yessy \& yusnaini. (2020). Counseling About Gout's Disease and Physical Training For Community In Stambul Jaya Village, Tanoh Alas Sub-District, Aceh Tenggara District, 2(September), 8691.

Syarifuddin, L. A., Taiyeb, A. M., \& Caronge, M. W. (2019). Hubungan Pola Makan dan Aktivitas Fisik dengan Kadar Asam Urat Dalam Darah Pada Penderita Asam Urat ( Gout ) di Wilayah Kerja Puskesmas Sabbangparu Kabupaten Wajo Relationship of Diet and Physical Activity with Blood Uric Acid Levels in Gout Patients in $\mathrm{t}$. Prosiding Seminar Nasioal Biologi VI, 372-381. Retrieved fromhttps://ojs.unm.ac.id/semnasbio/ article/viewFile/10579/6201 